Int. J. Dev. Biol. 66: 125-135 (2022)

https://doi.org/10.1387/ijdb.210110fp

\title{
Application of developmental principles for spinal cord repair after injury
}

\author{
FLORENTIA PAPASTEFANAKI* \\ Laboratory of Cellular and Molecular Neurobiology-Stem Cells, Hellenic Pasteur Institute, Athens, Greece
}

\begin{abstract}
The superiority of the mammalian central nervous system (CNS) compared with other vertebrates does not involve an advanced capacity for regeneration, and any injury results in irreversible functional loss. Spinal cord injury ( $\mathrm{SCl}$ ) is one example of CNS trauma affecting thousands of individuals, mostly young, each year. Despite enormous progress in our comprehension of the molecular and cellular mechanisms underlying the pathophysiology after $\mathrm{SCl}$, also providing targets for therapeutic interventions, no efficient therapy exists as yet, emphasizing the need for further research. A breadth of studies have demonstrated that, after $\mathrm{SCl}$, principles of development come into play either to promote or to prohibit spontaneous regeneration, and their appropriate manipulation has the potential to contribute towards functional recovery. In this overview, some of the most recent and important studies are discussed. These offer explicitly novel input from the field of development to the field of CNS repair regarding the modification of the inhibitory environment of the injured spinal cord - mainly referring to the glial scar - the activation of endogenous cell populations such as ependymal stem cells and oligodendrocyte precursor cells, and the developmental transcriptional program that is transiently activated in neurons after injury. Furthermore, current advances in stem cell technology are highlighted in terms of refinement and precise design of the appropriate stem cell population to be transplanted, not only for cell replacement but also for modulation of the host environment. As single-dimension applications have not yet proved clinically successful, it is suggested that combinatorial strategies tackling more than one target might be more effective.
\end{abstract}

KEYWORDS: regeneration, remyelination, stem cell transplantation, glial scar, gastruloids

\section{Introduction}

Traumatic spinal cord injury (SCl) is a devastating situation that often leads to significant life-long functional disabilities and huge costs in social and financial terms for patients and their families (Backx et al., 2018; Munce et al., 2016). The estimated annual global incidence is 40 to 80 cases per million of population, meaning that appr. three million people live with $\mathrm{SCl}$ (global prevalence), with 250,000 to 500,000 new cases reported each year (https://www. who.int/news-room/fact-sheets/detail/spinal-cord-injury) (Singhet al., 2014). Of note, since this article will appear in a special issue dedicated to Greece, in the greater Thessaloniki area in northern Greece, the annual crude incidence in 2009 was 33.6 per million, which is relatively higher than in other EU countries, and transportation accidents were the leading cause (51\%) (Divanoglou and Levi, 2009). The disabilities caused by a SCI depend on the severity of injury and its location on the spinal cord, and may include partial or complete loss of sensory function or motor control of arms, legs, and/or body and affect bowel or bladder control, breathing, heart rate, and blood pressure, making serious incidents lifethreatening (Katoh et al., 2019). Thus, SCl may render a person completely dependent on caregivers, while assistive technology

Abbreviations used in this paper: Ascl1, Achaete-Scute Family BHLH Transcription Factor 1;CAMP, Cyclicadenosinemonophosphate; CNS, central nervous system; CSPG, chondroitin sulfate proteoglycan; Cstb, cystatin B; Ctnnb1, Catenin Beta 1; ECM, extracellular matrix; Erk, Extracellular signal-regulated kinases; ESC, embryonic stem cell; FGF, fibroblast growth factor; GPR17, G-protein coupled receptor 17; Igf1, Insulin-like growth factor 1; iPSC, induced pluripotent stem cell; Kcna4, Potassium Voltage-Gated Channel Subfamily A Member 4; Kcna5, Potassium Voltage-Gated Channel Subfamily A Member 5; Klf3, Kruppel Like Factor 3; Klf7, Kruppel Like Factor 7; Mtor, Mechanistic Target Of Rapamycin; NMP, neuromesodermal progenitor; NPC, neural stem/precursorcell; OPC, oligodendrocyte precursor cell; PKA, protein kinase A; $\mathrm{PMN}$, motor neuron progenitor domain; PNS, peripheral nervous system; PSA-NCAM, polysialylated form of the neural cell adhesion molecule; PSC, pluripotent stem cell; Satb1, special AT-rich sequence-binding protein-1; SCI, spinal cord injury; Sox2, SRY (sex determining region Y)-box 2; Stfa1, stefin A1; Tgfa, Transforming Growth Factor Alpha; Wnt, Wingless-Type MMTV Integration Site Family, Member.

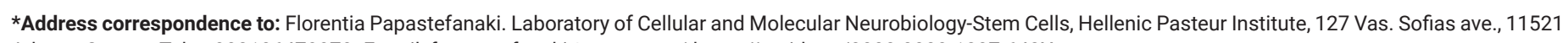
Athens, Greece. Tel.: +302106478870. E-mail: fpapastefanaki@pasteur.gr | https://orcid.org/0000-0003-1237-642X 
is often required to facilitate mobility, communication, and selfcare (Smith et al., 2016). Despite the wealth of relevant preclinical research and clinical trials, to date, the available pipeline includes limited options entailing surgical stabilization and decompression of the spinal cord, and rehabilitative care, while the only approved pharmacological approach is the administration of high-dosed methylprednizolone, despite serious concerns (Ahuja et al., 2017; Silva et al., 2014). Therefore, further insight into the molecular mechanisms underlying the pathophysiology after $\mathrm{SCl}$ is essential in order to provide novel therapeutic targets and dictate the design of effective interventions. In this direction, preclinical research in Greece in the field of SCl initially originated with contributions by our group (Lavdas et al., 2010; Matsas et al., 2008; Lavdas et al., 2011; Papastefanaki et al., 2007; Papastefanaki et al., 2015; Papastefanaki and Matsas, 2015) and was more recently expanded by the collaboration of four research groups in Crete (Kourgiantaki et al., 2020).

$\mathrm{SCl}$ triggers a cascade of detrimental molecular and cellular events prohibiting recovery in a complex sequel of neuropathology. Following primary damage that involves the disruption of meninges, hemorrhage, and massive death of neurons, oligodendrocytes and astrocytes, the cascade of secondary injury is initiated and divided into: (1) the acute phase (lasting hours to a couple of days) characterized by edema, hemorrhage, ischemia, inflammatory cell infiltration, release of cytotoxic products, excitotoxicity, apoptotic and necrotic cell

Fig. 1. Major cellular elements of the intact and injured spinal cord. Schematic representation of the intact spinal cord and of the different stages of spinal cord secondary injury that initiates after primary mechanical insult. During acute and subacute phases, a massive death of spinal cord cells is observed including, but not limited to, apoptotic and necrotic death of neurons and oligodendrocytes, the myelin forming cells of the CNS. The disruption of axonal integrity is followed be axonal degeneration, die-back, and demyelination of ascending and descending tracts, resulting to the loss of neural circuits. Events including hemorrhage, edema, disruption of the blood-spinal cord barrier, and release of cytotoxic byproducts and inflammatory molecules induces the activation of microglia and infiltration of peripheral macrophages for the clearance of the damaged tissue. At the same time, astrocytes become reactive and start forming the glial scar along with other cell types such as meningeal fibroblasts, and OPCs. The accumulation of ECM molecules, e.g., CSPGs, further contributes to the scar establishment. Ependymal stem cells are activated and differentiate majorly to astrocytes. During the chronic phase, axons continue to degenerate, whereas the persistence of some demyelinated spared axons is apparent. Surviving neurons may establish new connections, with the possibility of undesired functional consequences. OPCs insufficiently differentiate to myelinating oligodendrocytes and Schwann cells (myelin-forming cells normally found in the PNS). Any endogenous attempts for axonal regeneration and remyelination are prohibited by the consolidated glial scar that encloses the lesion core and acts as a physical and chemical barrier, the formation of cystic cavities but also by the sustained, yet moderately resolved, inflammation. death; (2) the subacute phase (days-couple of weeks) with ongoing edema and ischemia, persistent inflammatory cell infiltration causing further cell death, formation of the glial scar and of cysts; (3) the chronic phase (months-years) during which axonal degeneration and demyelination continue, the glial scar consolidates and together with cystic cavities inhibit any endogenous attempt for regeneration and functional restoration (Fig. 1) (Ahuja et al., 2017; Silva et al., 2014). Contributions to the failure of adult central nervous system (CNS) regeneration, also reflecting potential therapeutic targets, can be briefly summarized thus: the absence of permissive substrates for axonal growth in the lesion core (Hur et al., 2012; O'Shea et al., 2017); the adult neurons' failure to activate their intrinsic growth state (He and Jin, 2016; Mar et al., 2014; Tedeschi and Bradke, 2017); the presence of inhibitors to axon growth and myelination, in both adult myelin (Silver et al., 2014); and the extracellular matrix (ECM) that, along with several

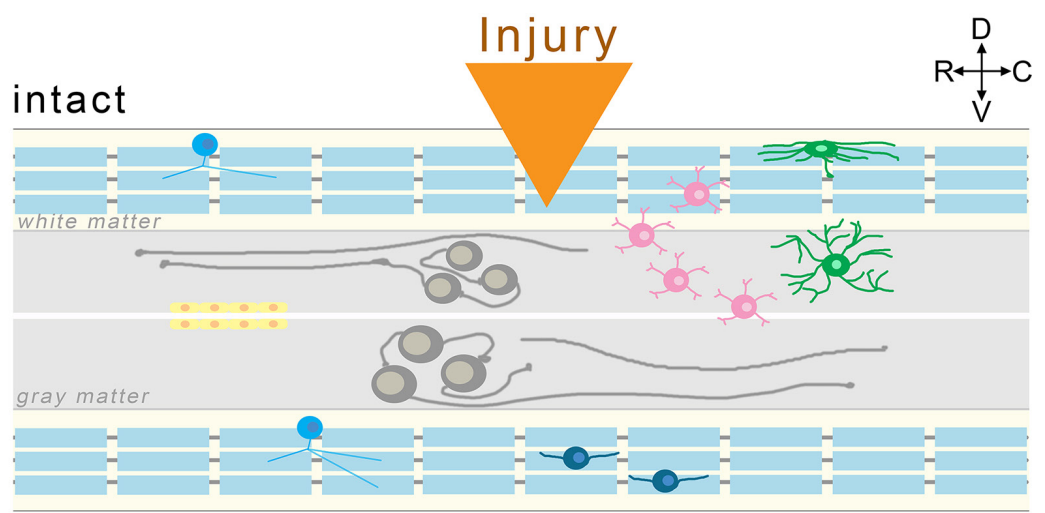

\section{acute/subacute}
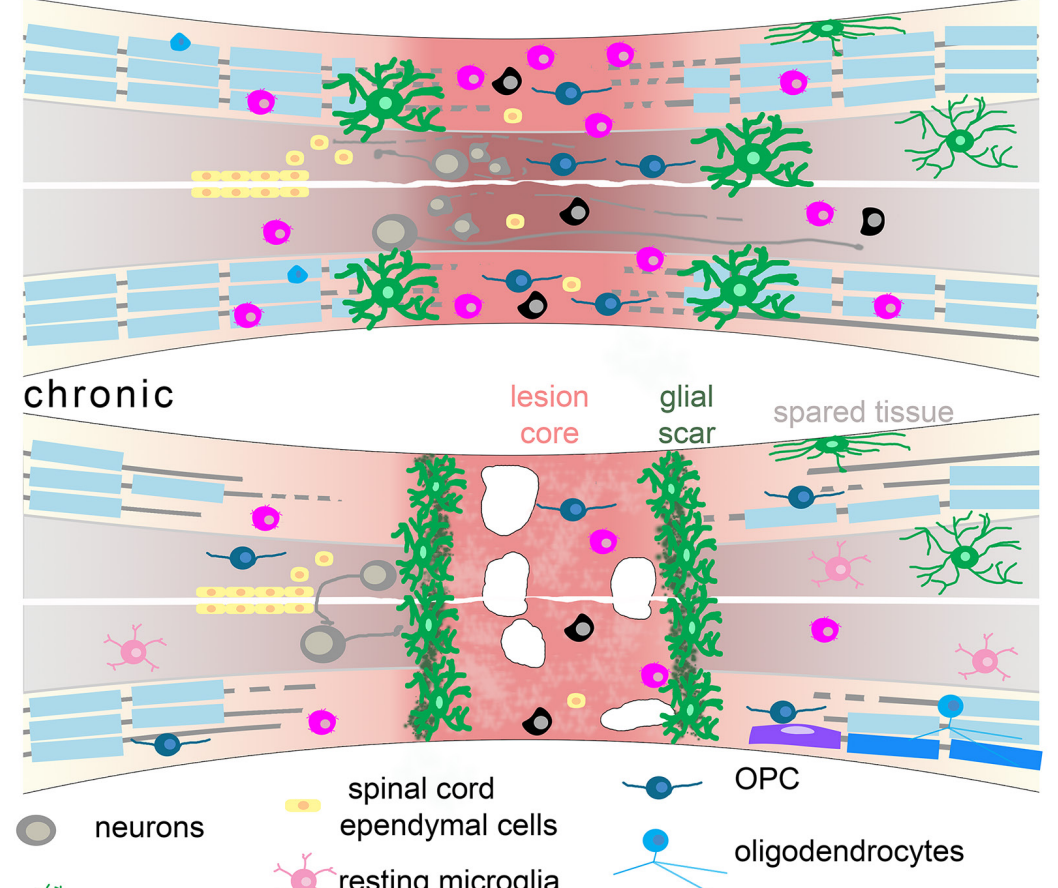

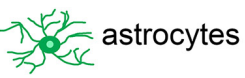

resting microglia

activated microglia

CNS myelin sheath

reactive

astrocytes

- macrophages

regenerated CNS myelin myelinating Schwann cell 
resident and infiltrating cell types, constitutes the glial scar (Fig. 1) (Bradbury and Burnside, 2019).

Interestingly, unlike the adult mammalian CNS, other organs, such as the skin and intestine, and, to a lesser extent, liver and pancreas, can regenerate (lismaa et al., 2018). Furthermore, the lack of regenerative potential of the adult mammalian CNS is a feature not shared with the peripheral nervous system (PNS) in which injured axons have the ability to regenerate, under certain circumstances (Abe and Cavalli, 2008), while there was historical evidence that injured CNS axons are able to regrow into peripheral nerve grafts (Benfey and Aguayo, 1982; David and Aguayo, 1981). More recently, it was demonstrated that peripheral nerve conditioning lesions enhance the regeneration of the central branch of sensory axons in the CNS by activation of the injured neurons' intrinsic growth state (Kumamaru et al., 2018b). Indeed, systems-level analysis of the intrinsic transcriptional program of regrowing peripheral neurons revealed that transcription factors and known signaling pathways are activated, while this is not the case in CNS injuries (Chandran et al., 2016). Moreover, lower vertebrates such as teleost fish and urodele amphibians evidence an impressive ability to regenerate their spinal cords throughout life, whereas anuran (tailless) amphibians are capable of spinal cord regeneration only until metamorphosis (Lee-Liu et al., 2013). Furthermore, the immature mammalian CNS is capable of limited regeneration (Avci et al., 2012); mice subjected to experimental SCI at postnatal day 2 (P2) are able to regenerate both serotonergic axons and axons of the corticospinal tract (CST), in contrast to mice that undergo SCl at P7, P20, or in the adult stage (Li et al., 2020). Altogether, the aforementioned observations have long brought up the questions of whether developmental mechanisms halted or latent in the adult could support CNS regeneration, if properly activated, and/or whether potentially reactivated growth programs fail to promote regeneration in the adult mammalian CNS due to restricting cues of the wounded CNS environment. In fact, several studies have shown that a variety of developmental mechanisms reemerge in the injured CNS tissue either inadequately to promote or to prohibit axonal regeneration and functional restoration. Such mechanisms and experimental approaches to bias them in favor of regeneration after $\mathrm{SCI}$ have been extensively discussed in other reviews (Cardozo et al., 2017; Garcia et al., 2018; Hilton and Bradke, 2017) that are strongly recommended.

All in all, the complex combination of several unfortunate conditions results in the detrimental lack of CNS regeneration, which from an evolutionary perspective has been preferred (or established) in adult mammals possibly because survival in the wild after a $\mathrm{SCl}$ is rare for both predators and prey, leaving insufficient time for natural selection to act otherwise, and/or because aberrant regeneration may lead to the establishment of malfunctioning circuits with serious, sometimes fatal, adverse effects such as autonomic dysreflexia, muscle spasticity, and neuropathic pain, at best minimizing the fitness of the subject (O'Shea et al., 2017); this could be the price that mammals must pay for the superior complexity of their CNS. Yet, recent research advancement has revealed important therapeutic targets, including developmental cues, which after manipulation could drive regeneration, and in combination with modern medicine and technological innovation could support functional recovery. Here, we narrow our focus and select some of the most recent studies that gained attention for revealing previously unknown developmental aspects that could be employed to promote CNS regeneration by either modifying the inhibitory environment of the injured tissue, by activating the hibernating developmental program of endogenous cells, or by providing exogenous cell populations in an active growth state to replace lost cell populations. The use of techniques such as bulk and single-cell transcriptomics, optogenetics and pharmacogenetics, trans-synaptic labeling and stem cell technological advances, provides valuable findings such as the contribution of microglia to the scar-free wound healing process observed in neonates, but also to the fate of parenchymal oligodendrocyte precursor cells (OPCs) after $\mathrm{SCl}$, the post-injury transcriptional regression of cortical neurons to a developmental state, and the inherent capacity of spinal cord neural stem/precursor cells (NPCs) to give rise to myelinating oligodendrocytes. In addition, we discuss cell transplantation approaches using specialized stem cells and the prospect of 3D stem cell assemblies that are (or could be) derived from human induced pluripotent stem cells (iPSCs) to support effective tissue reconstruction and regeneration with clinical relevance.

\section{How to restrict the glial scar taking lessons from neonatal microglia}

The glial scar and neuroinflammation are two major consequences of SCI (Fig. 1) (Bradbury and Burnside, 2019). Microglia - the resident cells that provide innate immunity in the CNS - are activated upon $\mathrm{SCl}$, while their role has been debated, since soon after injury the inflammatory reaction is necessary for the clearance of the damaged tissue and containment of the lesion site, but during chronic stages their persistent activation inhibits endogenous attempts at axonal regeneration and remyelination (David and Kroner, 2011; Zhou et al., 2014). Recently, it was shown that, similar to fish and amphibians that form glial bridges to support axonal regeneration across the lesion (Mokalled et al., 2016; Zukor et al., 2011), neonatal mice are capable of scar-free wound healing and spontaneous axon regrowth, and microglia were demonstrated to be the primary coordinator of this reparative reaction. This contrasts with what is observed in adults ( $\mathrm{Li}$ et al., 2020), in which, two weeks after SCl, the formation of the typical scar is observed surrounding the lesion core with accumulation of activated macrophages/microglia (Schafer et al., 2012), fibroblasts, reactive astrocytes, and ECM constituents, i.e., collagen type I, fibronectin, chondroitin sulfate proteoglycans (CSPGs), and laminin (Fig. 1) (Ahuja et al., 2017; Bradbury and Burnside, 2019; Silver et al., 2014). When P2 neonates were subjected to SCl, two weeks after injury the accumulation of activated macrophages/ microglia and deposition of ECM molecules was minimal, with a modest accumulation of reactive astrocytes within the lesion, while vascularization and axonal regrowth were recorded. Indeed, depletion of microglia in neonatal mice disrupted the healing process and stalled axonal regrowth. Depletion of microglia in the adult SCI results in impaired locomotor recovery, albeit the time-window of depletion might influence the outcome (Kroner and Rosas Almanza, 2019). In-depth single-cell RNA sequencing analysis revealed that neonatal microglia are transiently activated up to 7 days after injury and play a dual role in the scar-free healing process; on one hand, they transiently secrete fibronectin and its binding proteins to form bridges of ECM that connect the proximal and distal ends of the injured spinal cord, enabling axonal regrowth; on the other, they express several extracellular and intracellular peptidase inhibi- 
tors, such as Cstb, Stfa1, and Serpinb6a, which are involved in the resolution of inflammation, thereby minimizing chronic inhibition (Hammond et al., 2019; Li et al., 2019). These phenotypes are not present in the adult - fibronectin is persistently expressed by adult microglia and proteinase inhibitors are not induced after injury - and when neonatal microglia or adult microglia treated with peptidase inhibitors were transplanted in adult spinal cord lesions, in both cases significantly improved healing and axonal regrowth were observed (Li et al., 2020). These findings reveal important cellular and molecular mechanisms underlying the superior recovery of neonatal $\mathrm{SCl}$ as compared with the adult $\mathrm{SCl}$, and further suggest that these mechanisms could be employed therapeutically (alone or in combinatorial approaches, see below) to modify the hostile CNS environment in the adult and promote the healing process.

\section{Resident spinal cord neural stem cells and remyelination}

Besides modification of unfavorable characteristics presented by the CNS tissue after injury, myelin integrity, essential for the efficient and fast impulse conduction along neuronal axons, and its preservation and/or regeneration after $\mathrm{SCl}$, together with axonal regeneration, are of key importance for functional restoration. Loss of oligodendrocytes and myelin degradation are among the direct consequences of secondary damage, and while mature oligodendrocytes do not participate in the process of remyelination, there is some intrinsic but insufficient capacity for oligodendrogenesis and remyelination by the resident stem cells and OPCs (Fig. 1) that can be enhanced by axonal activity or manipulation of the immune response and the glial scar. Numerous therapeutic strategies have been presented with a view to restoration of myelin after $\mathrm{SCl}$, and some have even progressed to clinical trials. Yet, to date, the outcome has failed to fulfill expectations, suggesting that preclinical studies should continue focusing in seeking for additional therapeutic targets (Papastefanaki and Matsas, 2015).

NPCs reside in the adult brain and spinal cord and have been identified as presumptive suppliers of replacement cells for neurons, oligodendrocytes, and astrocytes lost after injury. However, their potential for cell generation after injury is almost exclusively in relation to astrocytes that build the glial scar, therefore they cannot support the replacement of neurons and oligodendrocytes that would restore the myelin profile (Barker et al., 2018; Benner et al., 2013; Faiz et al., 2015; Frisén, 2016). In the spinal cord in particular, the NPC reservoir is a small population of ependymal cells lining the wall of the central canal (Fig. 1) (Barnabe-Heider et al., 2010; Meletis et al., 2008). In the seminal recent study by Jonas Frisen's group, it was demonstrated that ependymal cells are in a permissive chromatin state that enables the induction of a latent gene expression program for oligodendrogenesis after $\mathrm{SCl}$, and that ectopic expression of the transcription factor Olig2 may promote abundant stem cell-derived oligodendrogenesis followed by oligodendrocyte differentiation, axon remyelination, and recovery of axonal conduction after SCI (Llorens-Bobadilla et al., 2020). Indeed, ependymal-derived oligodendrogenesis molecularly recapitulated developmental oligodendrogenesis (Llorens-Bobadilla et al., 2020), during which oligodendrocyte precursors undergo a step-wise differentiation process (Marques et al., 2016), sequentially turning on and off the respective gene expression program. This evidence indicates the potential for endogenous stem cell response to be manipulated to provide the necessary cell identities for functional recovery, such as oligodendrocytes in this case.

Directed ependymal cell-derived oligodendrogenesis could be synergistically combined with the regulated response of parenchymal OPCs. In another model of CNS injury - optic nerve injury - OPCs proliferate in response to injury and a small fraction differentiates into $\mathrm{CC} 1+$ immature oligodendrocytes. However, these cells never matured into myelinating oligodendrocytes even though regenerated and/or unmyelinated axons were present (Wang et al., 2020a). Pharmacological inhibition with Montelukast, a smallmolecule antagonist of G-protein coupled receptor 17 (GPR17, a critical regulator of oligodendrocyte development), induced OPC differentiation (Wang et al., 2020a). Overexpression of GPR17 inhibits oligodendrocyte differentiation and myelination (Chen et al., 2009), and after optic nerve injury it is potently upregulated, probably prohibiting OPC differentiation. Despite the positive effect of Montelukast treatment in OPC differentiation, the numbers of myelinating oligodendrocytes were still inadequate. In the same study (Wang et al., 2020a), the role of neuroinflammation in the regulation of remyelination was interrogated, and by pharmacologically depleting microglia with PLX3397 [a colony stimulating factor 1 receptor kinase inhibitor that effectively depletes microglia (Elmore et al., 2014)] it was demonstrated that, on one hand, microglia are critical for the early response of OPCs to injury while, on the other hand, they inhibit the maturation of oligodendrocytes at later stages after optic nerve injury. Combinatorial and timed treatment with Montelukast (one day post-injury) and PLX3397 (2 weeks post-injury) led to robust myelination and increased density of regenerated axons. Together with the aforementioned role of neonatal microglia in scar-free wound healing, these data indicate that a precise modulation of neuroinflammation could support different aspects of regeneration. Apparently, the time frame for the application of each suggested treatment is of paramount importance and should be carefully defined taking into consideration both the phase of secondary injury to be targeted (acute, subacute, or chronic) and the clinical relevance of such an application, since in real life, opportunities for therapeutic interventions, if any, arise after the patient has stabilized, most likely during the subacute and chronic phases (Ahuja et al., 2017).

\section{CST neurons revert to an immature transcriptional program sustained by NPC grafting}

The inherent incapacity of adult CNS neurons to regenerate ( $\mathrm{He}$ and Jin, 2016; Mar et al., 2014; Tedeschi and Bradke, 2017) is one of the main reasons for $\mathrm{CNS}$ repair failure, as already mentioned. The major descending pathway controlling voluntary movement in mammals is the CST that originates in the cerebral cortex and comprises the projections of cortical neurons into the spinal cord (Friedli et al., 2015; Oudega and Perez, 2012). It was recently demonstrated that SCI triggers a response in the CST neurons, driving them to an immature (correlating with an embryonic) transcriptional profile that was effectively sustained by transplantation of embryonic spinal cord NPCs over time, rather than initiating a new growth program (Poplawski et al., 2020). The CST axons were able to penetrate the NPC graft in the lesion site, starting 2 weeks after injury, remarkably extending and arborizing to form new synapses onto the grafted neurons (Poplawski et al., 2020). The improved regeneration was basically characterized basically by two transcriptional profiles in the corresponding cortical neurons: first, a reversion to an im- 
mature state, persisting during regeneration; second, temporally shifting patterns of gene expression, in which shortly after injury, anti-apoptotic cellular mechanisms were activated, shifting to the expression of genes that contribute to an active early regenerative state and finally - as axons extend into grafts and form synapses - the expression of axon guidance molecules and synaptic genes (Poplawski et al., 2020). In more detail, CST regeneration was associated with enrichment of signaling pathways of classic axonal growth, guidance, and synaptic plasticity, including members of the Erk family (Hollis et al., 2009), Mtor (Liu et al., 2010; Park et al., 2008), and Igf1, previously correlated with regeneration (Liu et al., 2017). Genes implicated in cell survival, proliferation, metabolism, and axon guidance, including Wnt genes, Ctnnb1, and genes involved in CAMP and PKA signaling, as well as growth factors (such as Igf1 and Tgfa) and transcription factors related to neuronal differentiation and axon regeneration (Sox2, Ascl1, KIf3, KIf7, Satb1, and Tp53), were upregulated in the pre-regenerative state and sustained over the 21-day period of regeneration. Indeed, genes involved in axon guidance (e.g., semaphorins, known as axon repellents), pathfinding, axonal transport, and encoding for cytoskeletal proteins were persistently upregulated. Of these, semaphorins were downregulated by day 21 in favor of axonal growth. In the early 14-day regenerative state, transcriptional networks related to protein translation, energy production, and mitochondrial function were activated, suggesting increased cell metabolism to cover the energy needs of axonal growth. In the late regenerative state, the expression of voltage-gated ion channels, including Kcna4 and Kcna5, was also induced, possibly reflecting the establishment of functional synapses (Poplawski et al., 2020). Importantly, in the absence of NPC grafts, the signature genes of embryogenesis were also upregulated, but started losing expression by 2 weeks after injury, evidencing that injured neurons can be appropriately reprogrammed toward an immature developmental state, to regenerate axons and rebuild neural networks only when found in an appropriate environment (i.e., the NPC graft).

\section{Stem cell transplantation for the treatment of SCI}

Apparently, endogenous stem cells are insufficient to support cell replacement and regeneration, unless exogenously manipulated. Alternatively, cell transplantation is among the most promising strategies to promote repair, and several early phase clinical trials have provided evidence that it is generally feasible (Saberi et al., 2011). Although the clinical outcomes have been poor, it is accepted that $\mathrm{SCl}$ treatment could benefit from the transplanted cells per se and/or from their secretome. Candidate cell types, including NPCs, OPCs, mesenchymal stem cells, Schwann cells, and olfactory ensheathing cells, alone or combined with other strategies, such as genetic modification to provide growth-promoting factors, application of biomaterials to support the graft and scaffold axonal regrowth, or factors to modulate the inhibitory environment (e.g., chondroitinase $A B C$, an enzyme that degrades CSPGs, constituents of the glial scar with inhibitory-to-regeneration properties), may exert neuroprotective and/or neuroregenerative roles (Assinck et al., 2017). In two of our relevant studies, we transplanted neonatal Schwann cells - the myelinating cells of the PNS, genetically modified for ectopic expression of the polysialylated form of the neural cell adhesion molecule (PSA-NCAM) (Papastefanaki et al., 2007) or overexpression of the L1 cell adhesion molecule (Lavdas et al.,
2010) on their membranes - in a mouse model of adult SCI. Both PSA-NCAM and L1 are cell adhesion molecules that participate in neurodevelopmental processes promoting axonal growth and myelination (Lavdas et al., 2011). Our strategy accelerated myelination by recruitment of resident OPCs and by the transplanted Schwann cells, and favored sprouting of regenerating serotonergic nerve fibers, essential for locomotor recovery that was also recorded (Lavdas et al., 2010; Papastefanaki et al., 2007). Importantly, unlike drugs or implanted biomaterials, transplanted cells are capable of responding to cues of the injured microenvironment and regulate their reciprocal interactions and fate (Ottoboni et al., 2020). Notwithstanding, accessibility and translational relevance of the sources for the proposed cell grafts reflect significant challenges in application. In this light, the breakthrough of induced pluripotent stem cell (iPSC) technology giving the opportunity to generate pluripotent stem cells directly from somatic cells, such as skin or blood cells, and then differentiate them, in principle, to any desired cell type, offers unprecedented opportunities for regenerative medicine and autologous grafting (Soldner and Jaenisch, 2018).

\section{Neural stem/precursor cells}

Functional improvement after SCl could benefit from the replacement of lost cells: neurons, capable of rebuilding the essential local circuits, facilitating axonal regrowth and pathfinding toward the denervated targets, and establishing new synapses; oligodendrocytes, capable of myelination of regenerated axons or remyelination of the spared demyelinated ones; and replacement of lost astrocytes, probably cautious since the fate of endogenous NPCs after injury is skewed toward the generation of new and reactive astrocytes that are major players in the regeneration processes, in both favorable and unfavorable ways (Ahuja et al., 2017; Assinck et al., 2017). From this standpoint, research advancement over the last decade in the field of stem cells has pointed to the significant potential of NPCs for transplantation approaches for the treatment of SCI. Mentioned already, transplantation of NPCs favors regeneration by maintaining the transcriptional growth program of endogenous cortical neurons activated (Poplawski et al., 2020). Besides, grafted NPCs have the ability to produce new neurons that generate synaptic relays between injured and target neurons of the host to reestablish neuronal communication. This relay formation could possibly be further refined by rehabilitative training and/or electrical stimulation to rewire the interrupted circuity and restore lost motor function (Lu et al., 2014). In addition, NPCs after transplantation generate glial cells that support the graft-derived neurons and also provide additional therapeutic cues, such as remyelination, neuroprotection, and modulation of the glial scar (Fischer et al., 2020). NPCs can be isolated from embryonic (with significant translational limitations including availability, histocompatibility, and ethical considerations) or adult (with translational challenges regarding the source accessibility) tissues, but they can also be produced by directed differentiation of iPSCs or direct reprogramming of non-neural cells, overcoming issues related to ethics, histocompatibility, and availability, but with limitations with regard to long preparation protocols, residual epigenetic memory, and safety against tumorigenesis (Vismara et al., 2017).

Increasing evidence suggests that the regional compatibility of grafted NPCs is important for their successful integration into the injured neural tissue and that specific and functionally-restricted connections between the graft and the host form spontaneously. 
Important work by the group led by Mark Tuszynski demonstrated homologous reconstitution of the lesioned adult spinal cord by grafting primary embryonic spinal cord tissue, with the graft-derived neurons forming synaptic relays across the lesion site (Kadoya et al., 2016; Lu et al., 2012) while also being myelinated by host oligodendrocytes (Hunt et al., 2017), supporting functional improvement. The synaptic integration of spinal cord NPC grafts was verified by the use of a comprehensive monosynaptic rabies virus mapping system that retrogradely traced host neurons (originating in the cortex, brainstem, spinal cord, and dorsal root ganglia) forming synapses onto graft-derived neurons (Adler et al., 2017). By contrast, when rostrally-fated (brain) NPCs were transplanted, CST axons did not regenerate (Kadoya et al., 2016) indicating that NPC grafts, to favor their integration in the injured spinal cord, should be derived through vertebrate posterior developmental processes. During spinal cord development, in parallel with the antero-posterior polarization, patterning of the neural tube specifies discrete progenitor domains along the dorsal/ventral axis that give rise to the major neuronal lineages (Lai et al., 2016). Impressively, spinal cord NPCs grafted into a rat model of spinal cord dorsal column injury were able to spontaneously self-assemble into organotypic, dorsal horn-like clusters with laminar organization of distinct dorsal spinal cord subtypes of interneurons, recapitulating normal developmental differentiation and specification programs to partially establish the cytoarchitecture of the intact spinal cord dorsal horns. These graftderived clusters were extensively innervated by regenerating host sensory axons - that normally send input to the dorsal horns of the intact spinal cord - but were avoided by CST axons, normally innervating motor interneurons (Dulin et al., 2018). Moreover, host sensory axon regeneration into the grafts was significantly higher in dorsal-restricted spinal cord NPC grafts than in ventral spinal cord graft clusters (Dulin et al., 2018). On the other hand, regenerating adult CST axons, without exogenous guidance, preferentially synapsed onto appropriate motor interneuron-rich domains within spinal cord NPC grafts, recapitulating patterns of the CST projection in the intact spinal cord, while avoiding graft-derived sensory targets (Kumamaru et al., 2019). These observations suggest that functionally relevant restoration of the complex spinal cord circuits after SCI may be achievable, and that injured, regenerating adult spinal cord axons retain their developmental ability to distinguish between appropriate and inappropriate targets when encountering NPC grafts (Adler et al., 2017; Ceto et al., 2020; Dulin et al., 2018; Koffler et al., 2019; Kumamaru et al., 2019). In a follow-up study, human embryonic stem cell (ESC)-derived spinal cord NPCs, grafted in the lesioned rat spinal cord, differentiated into a diverse population of spinal cord neurons occupying multiple positions along the dorso-ventral axis, and were maintained for long time periods. Grafts were rich in excitatory neurons, extended large numbers of axons over long distances, innervating target elements, and did indeed enable robust CST regeneration. The grafts synaptically integrated into multiple host intraspinal and supraspinal systems, including the CST, and provided, to some degree, functional restoration after injury (Kumamaru et al., 2018a). Further confirming the importance of anatomical relevance between donor cells and host tissue, human fetal spinal cord neuroepithelial stem cells were transplanted in the lesioned spinal cord of immunodeficient mice and displayed extensive integration in the host tissue, elongation of both graft and host axons, and relay formation leading to functional recovery (Dell'Anno et al., 2018). A step closer to clinical application, fetal human spinal cord-derived NPCs were grafted into sites of cervical $\mathrm{SCl}$ in rhesus monkeys (Macaca mulatta), under immunosuppression, after scaling up and modifying the transplantation techniques applied in rodents (Rosenzweig et al., 2018). Grafts were detected up to at least 9 months after injury, not actually migrating or forming ectopic colonies, expressing both neuronal and glial markers and

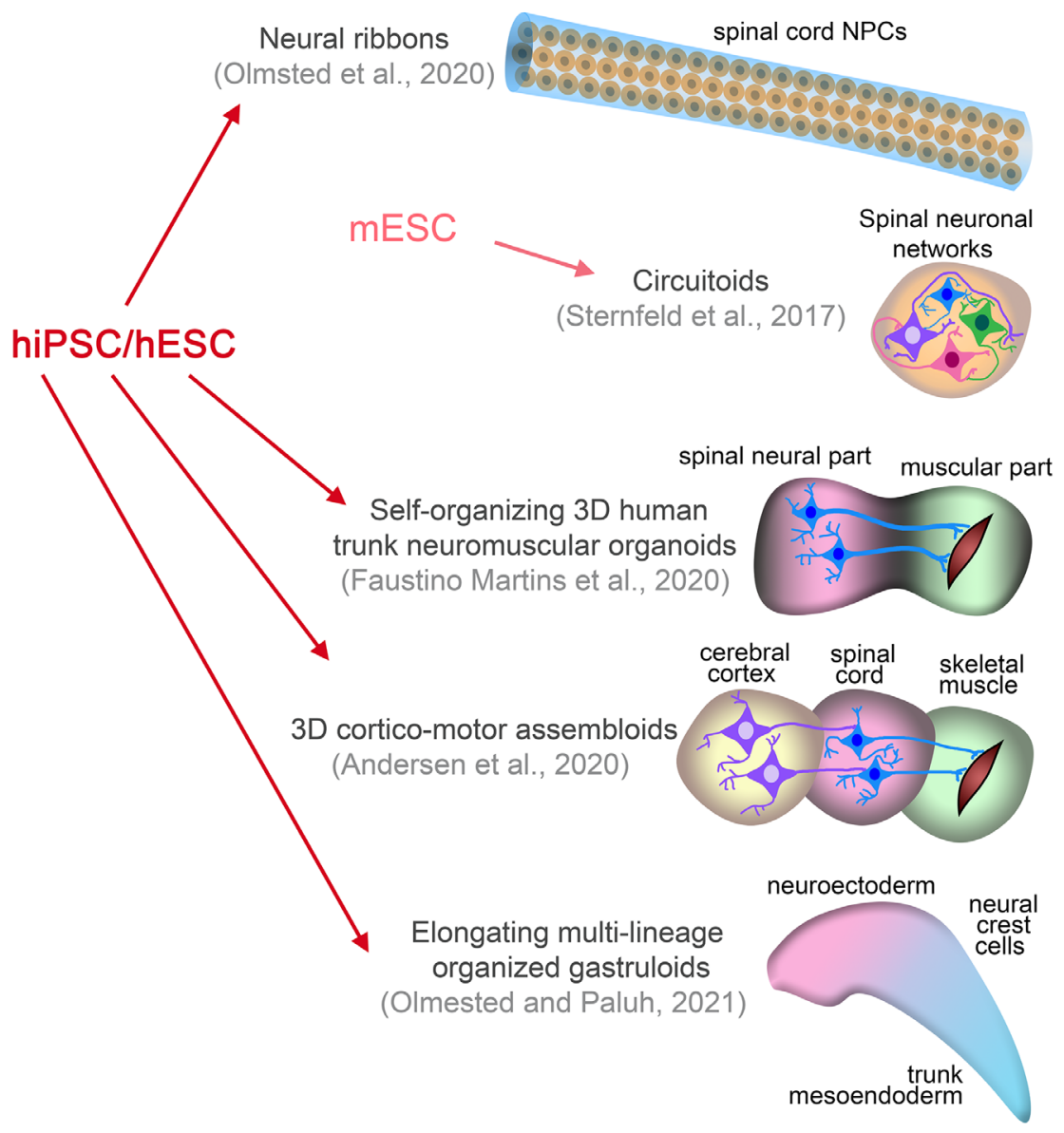

Fig. 2. Novel three-dimensional neural assemblies. Three-dimensional cellular in vitro formations, established by specifically induced differentiation of pluripotent stem cells to heterogeneous cell populations, have been demonstrated during the past few years. The less complex 'neural ribbons' represent human iPSC-derived NPCs encapsulated in a biodegradable hydrogel and suggest a transplantable cellular construct for the treatment of SCI. More complex self-organizing functional setups, including corticomotor assembloids, trunk neuromuscular organoids, circuitoids, and gastruloids were devised as in vitro models for the understanding of embryogenesis and organogenesis in a human setting and in the future could serve the comprehension of developmental mechanisms participating in the pathophysiology of SCl or even provide advanced transplantable 3D tissue formations. 
maturing over time, while human axons were observed to extend beyond the graft and host white matter, and formed synapses in the distal gray matter. In addition, host axons displayed synaptic connectivity within the graft, whereas improved forelimb function was recorded several months after transplantation (Rosenzweig et al., 2018). Thus, human pluripotent stem cell-derived spinal cord NSCs could enable a broad range of biomedical applications, not merely for in vitro disease modeling, but also providing an improved, clinically translatable, cell source for 'replacement' strategies for SCI.

Besides isolation from primary embryonic tissue, or directed differentiation from human ESCs or iPSCs, spinal cord NPCs can be derived from neuromesodermal progenitors (NMPs) that constitute a pool of caudal axial progenitor cells (Gouti et al., 2014; Tzouanacou et al., 2009) providing the regional specificity for application in SCls. NMPs (identified by the co-expression of the mesodermal transcription factor Brachyury and the NPC marker Sox2) were identified in the caudal lateral epiblast of the developing embryo and are characterized as the natural origin of the spinal cord and adjacent mesodermal somites, while they also produce neural crest cells in subsequent stages (Gouti et al., 2015). In a recent study, formations named 'neural ribbons' were fabricated in degradable hydrogel to home spinal cord NPCs coming from human iPSC-derived NMPs (Fig. 2). Bipotent NMPs were induced by defined Wnt/FGF treatment and further neuralized by dual SMAD inhibition and Notch signaling inhibition to prevent endodermal and mesodermal differentiation. The spinal cord NPCs produced were patterned toward cervical identity by exposure to retinoic acid during differentiation and were also directed to the ventral fate of the motor neuron progenitor domain $(\mathrm{pMN})$ of the dorso-ventral patterning axis by the addition of a sonic hedgehog agonist in culture (Olmsted et al., 2020). After extensive characterization, the patterned spinal cord NPCs were encapsulated in a biodegradable alginate-based hydrogel and templated into neural ribbons by passing them through a needle tip. The rationale was for the NPC graft to be protected in a matrix from the deleterious environment of the injured spinal cord. Survival and differentiation of the NPCs was verified in the alginate biomaterial that was also successfully evaluated as a molecular carrier of chondroitinase $A B C$, suggesting that the neural ribbons offer a novel means not only for cell but also for drug delivery. In a proof-of-concept trial, the neural ribbons were transplanted in a rat model of cervical contusion injury and displayed improved survival and process extension across the lesion cavity border, compared with equivalent number of cells grafted in suspension (Olmsted et al., 2020). Therefore, this combinatorial approach of homotypic regionalized NPCs encapsulated in alginate-based biomaterial constitutes a protective 3D platform for cell delivery, retention, and positioning in $\mathrm{SCI}$ with potential therapeutic value (Fig. 2) (Olmsted et al., 2020).

\section{The prospect of three-dimensional neural assemblies}

The technological innovation of stem cell-derived, self-organizing three-dimensional (3D) structures, also referred to as organoids, has demonstrated considerable potential to reproduce the cellular and structural complexity of the CNS tissue that cannot be captured in monolayer culture systems (Mansour et al., 2021). Thus, the ultimate goal of stem cell biology, to apply principles learned from developmental biology for the generation of cells and tissues that mimic their in vivo counterparts and facilitate the study of otherwise inaccessible live human tissues, is being served in an revolutionary manner, and this explains the growing scientific interest in such systems (Mansour et al., 2021). Indeed, brain (Birey et al., 2017; Lancaster et al., 2013) and spinal cord (Andersen et al., 2020; Duval et al., 2019; Meinhardt et al., 2014; Ogura et al., 2018) organoids - apart from their profound role as advanced models for studying CNS development and pathophysiology in a human (and personalized, if necessary) setting - could be foreseen as biological, transplantable, 3D constructs comprising different essential cell populations, with or without disturbance of their favorable niche. The regional specificity to which brain and spinal cord organoids can be directed (Mansour et al., 2021), is a desired feature for cell replacement approaches, as discussed above. Interestingly, to improve the survival of brain organoids through vascularization (a crucial element missing from organoids grown in culture) and to study connectivity patterns under physiological conditions, two recent studies described the methodological transplantation of cerebral organoids into neonatal (Daviaud et al., 2018) and adult (Mansour et al., 2018) mouse brains, and reported effective vascularization, preservation of the organoid's cytoarchitecture and progressive differentiation into neuronal and glial fates along with long-term maturation, increased survival, and synaptic integration in the host tissue. Moreover, brain (Kitahara et al., 2020; Wang et al., 2020b) and spinal cord (Lai et al., 2018) organoids have already been transplanted in animal models of relevant injuries.

Lai et al. combined neuronal and oligodendroglial induction techniques on spinal cord NPCs and developed a novel spinal cord-like tissue construct with modular assemblies of white matterlike and gray matter-like tissues with distinct placement into a collagen sponge columnar substrate (separately cultured at the beginning and combined at later stages), to resemble the in vivo architecture of the spinal cord. The spinal cord-like tissue constructs were transplanted in a rat model of spinal cord transection and, two months later, the injured rats were recorded with significant recovery of their hind limb motor function and electrophysiological presentation, compared with controls (Lai et al., 2018). In the white matter module located at the periphery of the graft, graft-derived myelin sheaths were detected wrapping around axons, whereas in the central compartment of the gray matter module the majority of the cells were neurons and astrocytes. Graft-derived neurons extended processes that supported host-regenerating axons in reinnervation while also being remyelinated. Moreover, descending serotonergic and ascending sensory fibers were seen to regenerate and grow through the graft to the opposite side, also forming synaptic contacts with the graft-derived neurons (Lai et al., 2018). Although this is the first and, to date, the only study reporting transplantation of a 3D construct with multicellular organization in $\mathrm{SCl}$ that requires reproduction, it provides proof of concept that bioengineering-based regenerative medicine has entered a new era of application of implantable prebuilt tissue such as organoids for functional CNS restoration.

As pointed out above, grafts such as stem cells and organoids that represent early developmental stages of the relevant tissue/ organ may have remarkable therapeutic potential due to the expected reciprocal interactions with the host tissue environment and the increasingly appreciated neural plasticity facilitated through the principles of developmental axonal growth that could promote regeneration in the adult CNS (Hilton and Bradke, 2017; Poplawski et al., 2020). However, specialized organoids, such as cerebral 
organoids or spinal cord organoids lack important structures of other, except for the neuroectoderm, germ layer origins, including vasculature, microglia, peripheral immune cells (mesodermal origin), and neural crest-derived Schwann cells, all playing major roles in spinal cord repair after injury. Therefore, the cellular complexity of the CNS is not accurately represented, and long-term viability and maturation are confined, also questioning organoids' therapeutic potential (Mansour et al., 2021). 3D structures more complex than single organoids have already been presented, comprising more than one region of the CNS or even different tissues, and some of the most exciting examples are as follows (Fig. 2). Three-dimensional cortico-motor assembloids were originally established by the group led by S. Pasca, and represent 3D cultures formed from the functional fusion of three independent spheroids resembling the cerebral cortex, the hindbrain/spinal cord, and skeletal muscle, all derived from human iPSCs (Andersen et al., 2020). Self-organizing $3 \mathrm{D}$ human trunk neuromuscular organoids were developed by $\mathrm{M}$. Gouti's group, which took advantage of the bipotency of NMPs and generated dual organoids with neural and muscular modules (Faustino Martins et al., 2020), functionally connected with neuromuscular junctions. Circuitoids were presented as synthetic microphysical neural networks that comprise precise combinations of spinal neuron subtypes (both excitatory and inhibitory) derived from mouse stem cells, and allow the investigation of the control of oscillatory properties that emerge in interconnected neuronal networks (Sternfeld et al., 2017). Gastruloids are 3D culture systems that can recapitulate early mammalian embryogenesis in a multilineage context with significant accuracy. The first studies used mouse ESC-and human ESC-derived gastruloids to investigate the anterior-posterior organization. Similar structures were used for the in vitro demonstration of embryogenesis events such as symmetry breaking, axial elongation, somitogenesis, and cardiogenesis (Sahu and Sharan, 2020). Very recently, an elongating multi-lineage organized gastruloid system was established from NMPs to study co-developing central and peripheral neuronal systems with trunk mesoendoderm. A forty-day evaluation of both ectodermal cells and non-ectodermal neural crest cells revealed that neural crest cells differentiate to peripheral neurons and integrate with an upstream spinal cord region after eight days. Polarization events follow in coordination with endoderm differentiation and primitive gut tube formation during multicellular spatial reorganization (Olmsted and Paluh, 2021). This combined human CNS-PNS model of early organogenesis provides a toolbox for interrogating developmental events of mesendoderm and neuromuscular trunk regions and enables systemic studies of tissue interactions and innervation of neuromuscular, enteric, and cardiac systems.

\section{Summary}

Undoubtedly, human CNS repair represents a major challenge to modern neuroscience and medicine, due to the huge and permanent impact of CNS injuries on patients in medical, social, and financial terms. Unfortunately, the progress made in preclinical research is not reflected in clinical trials, which have failed to provide even moderate functional improvement, questioning the validity of animal and other preclinical models. However, the knowledge already gathered is of real importance because it provides potential targets to pursue or pitfalls to avoid when designing a novel approach. For example, it is widely accepted that therapeutic approaches (each one alone or in combination) should target the three major modules of SCI neuropathology, i.e., the inhibitory environment of the injured tissue, the lack of permissive substrates in the lesion site, and the incapacity of adult CNS neurons to activate their growth program. The exploitation of neurodevelopmental principles in favor of CNS regeneration is indeed a promising approach that stems from the results of fundamental research demonstrating that mechanisms of embryogenesis and organogenesis, hibernated in the adult, are moderately (and apparently inadequately) reactivated during spontaneous regeneration processes. Moreover, the field of stem cells has exhibited remarkable progress, enabling future research more efficiently to incorporate stem cell transplantation in the treatment of SCl. Alongside advancements in bioengineering, stem cells could serve the design of transplants with favorable properties in terms of survival and integration in the host tissue, anatomical compatibility and immune-compatibility, as well as translational relevance. In the future, three-dimensional stem cell assemblies are expected to provide specialized transplants with unique properties in addition to serving as preclinical humanized models that in combination with existing in vivo models would pave the way toward more translationable results.

\section{References}

ABE N., CAVALLI V. (2008). Nerve injury signaling. Current Opinion in Neurobiology 18: 276-283. https://doi.org/10.1016/j.conb.2008.06.005

ADLER A. F., LEE-KUBLI C., KUMAMARU H., KADOYA K., TUSZYNSKI M. H. (2017) Comprehensive Monosynaptic Rabies Virus Mapping of Host Connectivity with Neural Progenitor Grafts after Spinal Cord Injury. Stem Cell Reports 8: 1525-1533. https://doi.org/10.1016/j.stemcr.2017.04.004

AHUJA C. S., WILSON J. R., NORI S., KOTTER M. R. N., DRUSCHEL C., CURT A., FEHLINGS M. G. (2017). Traumatic spinal cord injury. Nature Reviews Disease Primers 3: 17018. https://doi.org/10.1038/nrdp.2017.18

ANDERSEN J., REVAH O., MIURA Y., THOM N., AMIN N. D., KELLEY K. W., SINGH M., CHEN X., THETE M. V., WALCZAK E. M., VOGEL H., FAN H. C., PAŞCA S. P. (2020). Generation of Functional Human 3D Cortico-Motor Assembloids. Cell 183: 1913-1929.e26. https://doi.org/10.1016/j.cell.2020.11.017

ASSINCK P., DUNCAN G. J., HILTON B. J., PLEMEL J. R., TETZLAFF W. (2017). Cell transplantation therapy for spinal cord injury. Nature Neuroscience 20: 637-647. https://doi.org/10.1038/nn.4541

AVCI H. X., LEBRUN C., WEHRLE R., DOULAZMI M., CHATONNET F., MOREL M.P. EMA M., VODJDANI G., SOTELO C., FLAMANT F., DUSART I. (2012). Thyroid hormone triggers the developmental loss of axonal regenerative capacity via thyroid hormone receptor 1 and kruppel-like factor 9 in Purkinje cells. Proceedings of the National Academy of Sciences 109: 14206-14211. https://doi.org/10.1073/ pnas. 1119853109

BACKX A. P. M., SPOOREN A. I. F., BONGERS-JANSSEN H. M. H., BOUWSEMA H. (2018). Quality of life, burden and satisfaction with care in caregivers of patients with a spinal cord injury during and after rehabilitation. Spinal Cord 56: 890-899. https://doi.org/10.1038/s41393-018-0098-7

BARKER R. A., GÖTZ M., PARMAR M. (2018). New approaches for brain repairfrom rescue to reprogramming. Nature 557: 329-334. https://doi.org/10.1038/ s41586-018-0087-1

BARNABÉ-HEIDER F., GÖRITZ C., SABELSTRÖM H., TAKEBAYASHI H., PFRIEGER F. W., MELETIS K., FRISÉN J. (2010). Origin of New Glial Cells in Intact and Injured Adult Spinal Cord. Cell Stem Cell 7: 470-482. https://doi.org/10.1016/j. stem.2010.07.014

BENFEY M., AGUAYO A. J. (1982). Extensive elongation of axons from rat brain into peripheral nerve grafts. Nature 296: 150-152. https://doi.org/10.1038/296150a0

BENNERE. J., LUCIANO D., JO R., ABDI K., PAEZ-GONZALEZ P., SHENG H., WARNER D. S., LIU C., EROGLU C., KUO C. T. (2013). Protective astrogenesis from the SVZ niche after injury is controlled by Notch modulator Thbs4. Nature 497: 369-373. https://doi.org/10.1038/nature12069 
BIREY F., ANDERSEN J., MAKINSON C. D., ISLAM S., WEI W., HUBER N., FAN H. C., METZLER K. R. C., PANAGIOTAKOS G., THOM N., O'ROURKE N. A., STEINMETZ L. M., BERNSTEIN J. A., HALLMAYER J., HUGUENARD J. R., PAŞCA S. P. (2017). Assembly of functionally integrated human forebrain spheroids. Nature 545: 54-59. https://doi.org/10.1038/nature22330

BRADBURY E. J., BURNSIDE E. R. (2019). Moving beyond the glial scar for spinal cord repair. Nature Communications 10: 3879. https://doi.org/10.1038/s41467019-11707-7

CARDOZO M. J., MYSIAK K. S., BECKER T., BECKER C. G. (2017). Reduce, reuse, recycle - Developmental signals in spinal cord regeneration. Developmental Biology 432: 53-62. https://doi.org/10.1016/j.ydbio.2017.05.011

CETO S., SEKIGUCHI K. J., TAKASHIMA Y., NIMMERJAHN A., TUSZYNSKI M. H. (2020). Neural Stem Cell Grafts Form Extensive Synaptic Networks that Integrate with Host Circuits after Spinal Cord Injury. Cell Stem Cell 27: 430-440.e5. https:// doi.org/10.1016/j.stem.2020.07.007

CHANDRAN V., COPPOLA G., NAWABI H., OMURA T., VERSANO R., HUEBNER E. A., ZHANG A., COSTIGAN M., YEKKIRALA A., BARRETT L., BLESCH A., MICHAELEVSKI I., DAVIS-TURAK J., GAO F., LANGFELDER P., HORVATH S., HEZ., BENOWITZL., FAINZILBERM., TUSZYNSKI M., WOOLF C. J., GESCHWIND D. H. (2016). A Systems-Level Analysis of the Peripheral Nerve Intrinsic Axonal Growth Program. Neuron 89: 956-970. https://doi.org/10.1016/j.neuron.2016.01.034

CHEN Y., WU H., WANG S., KOITO H., LI J., YE F., HOANG J., ESCOBAR S. S., GOW A., ARNETT H. A., TRAPP B. D., KARANDIKAR N. J., HSIEH J., LU Q. R. (2009). The oligodendrocyte-specific $G$ protein-coupled receptor GPR17 is a cell-intrinsic timer of myelination. Nature Neuroscience 12: 1398-1406. https:// doi.org/10.1038/nn.2410

DAVIAUD N., FRIEDEL R. H., ZOU H. (2018). Vascularization and Engraftment of Transplanted Human Cerebral Organoids in Mouse Cortex. eneuro 5: ENEURO.0219-18.2018. https://doi.org/10.1523/ENEURO.0219-18.2018

DAVID S., AGUAYO A. J. (1981). Axonal Elongation into Peripheral Nervous System «Bridges» After Central Nervous System Injury in Adult Rats. Science 214: 931933. https://doi.org/10.1126/science.6171034

DAVID S., KRONER A. (2011). Repertoire of microglial and macrophage responses after spinal cord injury. Nature Reviews Neuroscience 12: 388-399. https://doi. org/10.1038/nrn3053

DELL'ANNO M. T., WANG X., ONORATI M., LI M., TALPO F., SEKINE Y., MA S., LIU F., CAFFERTY W. B. J., SESTAN N., STRITTMATTER S. M. (2018). Human neuroepithelial stem cell regional specificity enables spinal cord repair through a relay circuit. Nature Communications 9: 3419. https://doi.org/10.1038/s41467-018-05844-8

DIVANOGLOU A., LEVI R. (2009). Incidence of traumatic spinal cord injury in Thessaloniki, Greece and Stockholm, Sweden: a prospective population-based study. Spinal Cord 47: 796-801. https://doi.org/10.1038/sc.2009.28

DULIN J. N., ADLER A. F., KUMAMARU H., POPLAWSKI G. H. D., LEE-KUBLI C., STROBL H., GIBBS D., KADOYA K., FAWCETT J. W., LU P., TUSZYNSKI M. H. (2018). Injured adult motor and sensory axons regenerate into appropriate organotypic domains of neural progenitor grafts. Nature Communications 9: 84. https://doi.org/10.1038/s41467-017-02613-x

DUVAL N., VASLIN C., BARATA T., FRARMA Y., CONTREMOULINS V., BAUDIN X., NÉDÉLEC S., RIBES V. (2019). BMP4 patterns Smad activity and generates stereotyped cell fate organisation in spinal organoids. Development 146: dev175430. https://doi.org/10.1242/dev.175430

ELMORE M. R.P., NAJAFI A. R., KOIKE M. A., DAGHER N. N., SPANGENBERG E. E., RICE R. A., KITAZAWA M., MATUSOW B., NGUYEN H., WEST B. L., GREEN K. N. (2014). Colony-Stimulating Factor 1 Receptor Signaling Is Necessary for Microglia Viability, Unmasking a Microglia Progenitor Cell in the Adult Brain. Neuron 82: 380-397. https://doi.org/10.1016/j.neuron.2014.02.040

FAIZ M., SACHEWSKY N., GASCÓN S., BANG K.W. A., MORSHEAD C. M., NAGY A. (2015). Adult Neural Stem Cells from the Subventricular Zone Give Rise to Reactive Astrocytes in the Cortex after Stroke. Cell Stem Cell 17: 624-634. https://doi. org/10.1016/j.stem.2015.08.002

FAUSTINO MARTINS J.M., FISCHER C., URZI A., VIDAL R., KUNZ S., RUFFAULT P.L., KABUSS L., HUBE I., GAZZERRO E., BIRCHMEIER C., SPULER S., SAUER S., GOUTI M. (2020). Self-Organizing 3D Human Trunk Neuromuscular Organoids. Cell Stem Cell 26: 172-186.e6. https://doi.org/10.1016/j.stem.2019.12.007

FISCHER I., DULIN J. N., LANE M. A. (2020). Transplanting neural progenitor cells to restore connectivity after spinal cord injury. Nature Reviews Neuroscience 21: 366-383. https://doi.org/10.1038/s41583-020-0314-2
FRIEDLI L., ROSENZWEIG E. S., BARRAUD Q., SCHUBERT M., DOMINICI N., AWAI L., NIELSON J. L., MUSIENKO P., NOUT-LOMAS Y., ZHONG H., ZDUNOWSKI S., ROY R. R., STRAND S. C., VAN DEN BRAND R., HAVTON L. A., BEATTIE M. S., BRESNAHAN J. C., BÉZARD E., BLOCH J., EDGERTON V. R., FERGUSON A. R., CURT A., TUSZYNSKI M. H., COURTINE G. (2015). Pronounced species divergence in corticospinal tract reorganization and functional recovery after lateralized spinal cord injury favors primates. Science Translational Medicine 7 302ra134. https://doi.org/10.1126/scitransImed.aac5811

FRISÉN J. (2016). Neurogenesis and Gliogenesis in Nervous System Plasticity and Repair. Annual Review of Cell and Developmental Biology 32: 127-141. https://doi. org/10.1146/annurev-cellbio-111315-124953

GARCIA A.L., UDEH A., KALAHASTY K., HACKAM A.S. (2018). A growing field: The regulation of axonal regeneration by Wnt signaling. Neural Regeneration Research 13: 43. https://doi.org/10.4103/1673-5374.224359

GOUTI M., METZIS V., BRISCOE J. (2015). The route to spinal cord cell types: a tale of signals and switches. Trends in Genetics 31:282-289. https://doi.org/10.1016/j. tig.2015.03.001

GOUTI M., TSAKIRIDIS A., WYMEERSCH F. J., HUANG Y., KLEINJUNG J., WILSON V., BRISCOE J. (2014). In Vitro Generation of Neuromesodermal Progenitors Reveals Distinct Roles for Wnt Signalling in the Specification of Spinal Cord and Paraxial Mesoderm Identity. PLoS Biology 12: e1001937.https://doi.org/10.1371/ journal.pbio. 1001937

HAMMOND T. R., DUFORT C., DISSING-OLESEN L., GIERA S., YOUNG A., WYSOKER A., WALKER A. J., GERGITS F., SEGEL M., NEMESH J., MARSH S. E., SAUNDERS A., MACOSKO E., GINHOUXF., CHEN J., FRANKLIN R. J.M.,PIAOX., MCCARROLL S. A., STEVENS B. (2019). Single-Cell RNA Sequencing of Microglia throughout the Mouse Lifespan and in the Injured Brain Reveals Complex Cell-State Changes. Immunity 50: 253-271.e6. https://doi.org/10.1016/j.immuni.2018.11.004

HE Z., JIN Y. (2016). Intrinsic Control of Axon Regeneration. Neuron 90: 437-451. https://doi.org/10.1016/j.neuron.2016.04.022

HILTON B. J., BRADKE F. (2017). Can injured adult CNS axons regenerate by recapitulating development?. Development 144:3417-3429. https://doi.org/10.1242/ $\operatorname{dev} .148312$

HOLLIS E. R., JAMSHIDI P., LÖW K., BLESCH A., TUSZYNSKI M. H. (2009). Induction of corticospinal regeneration by lentiviral trkB-induced Erk activation. Proceedings of the National Academy of Sciences 106: 7215-7220. https://doi.org/10.1073/ pnas.0810624106

HUNT M., LU P., TUSZYNSKI M. H. (2017). Myelination of axons emerging from neural progenitor grafts after spinal cord injury. Experimental Neurology 296: 69-73. https://doi.org/10.1016/j.expneurol.2017.07.005

HUR E. M., SAIJILAFU, ZHOU F. Q. (2012). Growing the growth cone: remodeling the cytoskeleton to promote axon regeneration. Trends in Neurosciences 35: 164-174. https://doi.org/10.1016/j.tins.2011.11.002

IISMAA S. E., KAIDONIS X., NICKS A. M., BOGUSH N., KIKUCHI K., NAQVI N., HARVEY R. P., HUSAIN A., GRAHAM R. M. (2018). Comparative regenerative mechanisms across different mammalian tissues. npj Regenerative Medicine 3 6. https://doi.org/10.1038/s41536-018-0044-5

KADOYA K., LU P., NGUYEN K., LEE-KUBLI C., KUMAMARU H., YAO L., KNACKERT J., POPLAWSKI G., DULIN J. N., STROBL H., TAKASHIMA Y., BIANE J., CONNER J., ZHANG S.C., TUSZYNSKI M. H. (2016). Spinal cord reconstitution with homologous neural grafts enables robust corticospinal regeneration. Nature Medicine 22: 479-487. https://doi.org/10.1038/nm.4066

KATOH H., YOKOTA K., FEHLINGS M. G. (2019). Regeneration of Spinal Cord Connectivity Through Stem Cell Transplantation and Biomaterial Scaffolds. Frontiers in Cellular Neuroscience 13: 248. https://doi.org/10.3389/fncel.2019.00248

KITAHARA T., SAKAGUCHI H., MORIZANE A., KIKUCHI T., MIYAMOTO S., TAKAHASHI J. (2020). Axonal Extensions along Corticospinal Tracts from Transplanted Human Cerebral Organoids. Stem Cell Reports 15: 467-481. https://doi. org/10.1016/j.stemcr.2020.06.016

KOFFLER J., ZHU W., QU X., PLATOSHYN O., DULIN J. N., BROCK J., GRAHAM L., LU P., SAKAMOTO J., MARSALA M., CHEN S., TUSZYNSKI M. H. (2019). Biomimetic 3D-printed scaffolds for spinal cord injury repair. Nature Medicine 25: 263-269. https://doi.org/10.1038/s41591-018-0296-z

KOURGIANTAKI A., TZERANIS D. S., KARALI K., GEORGELOU K., BAMPOULA E., PSILODIMITRAKOPOULOS S., YANNAS I. V., STRATAKIS E., SIDIROPOULOU K., CHARALAMPOPOULOS I., GRAVANIS A. (2020). Neural stem cell delivery via porous collagen scaffolds promotes neuronal differentiation and locomotion recovery in spinal cord injury. npj Regenerative Medicine 5: 12. https://doi. org/10.1038/s41536-020-0097-0 
KRONER A., ROSAS ALMANZA J. (2019). Role of microglia in spinal cord injury. Neuroscience Letters 709: 134370. https://doi.org/10.1016/j.neulet.2019.134370

KUMAMARU H., KADOYA K., ADLER A. F., TAKASHIMA Y., GRAHAM L., COPPOLA G., TUSZYNSKI M. H. (2018a). Generation and post-injury integration of human spinal cord neural stem cells. Nature Methods 15: 723-731. https://doi. org/10.1038/s41592-018-0074-3

KUMAMARU H., LU P., ROSENZWEIG E. S., KADOYA K., TUSZYNSKI M. H. (2019). Regenerating Corticospinal Axons Innervate Phenotypically Appropriate Neurons within Neural Stem Cell Grafts. Cell Reports 26: 2329-2339.e4. https://doi. org/10.1016/j.celrep.2019.01.099

KUMAMARU H., LU P., ROSENZWEIG E. S., TUSZYNSKI M. H. (2018b). Activation of Intrinsic Growth State Enhances Host Axonal Regeneration into Neural Progenitor Cell Grafts. Stem Cell Reports 11: 861-868. https://doi.org/10.1016/j. stemcr.2018.08.009

LAI B.Q., FENG B., CHE M.T., WANG L.J., CAI S., HUANG M.Y., GU H.Y., JIANG B., LING E.A., LI M., ZENG X., ZENG Y.S. (2018). A Modular Assembly of Spinal Cord-Like Tissue Allows Targeted Tissue Repair in the Transected Spinal Cord. Advanced Science 5: 1800261. https://doi.org/10.1002/advs.201800261

LAI H. C., SEAL R. P., JOHNSON J. E. (2016). Making sense out of spinal cord somatosensory development.Development 143:3434-3448. https://doi.org/10.1242/ dev.139592

LANCASTER M. A., RENNER M., MARTIN C.A., WENZEL D., BICKNELL L. S., HURLES M. E., HOMFRAY T., PENNINGER J. M., JACKSON A. P., KNOBLICH J. A. (2013). Cerebral organoids model human brain development and microcephaly. Nature 501: 373-379. https://doi.org/10.1038/nature12517

LAVDAS A. A., CHEN J., PAPASTEFANAKI F., CHEN S., SCHACHNER M., MATSAS R., THOMAIDOU D. (2010). Schwann cells engineered to express the cell adhesion molecule L1 accelerate myelination and motor recovery after spinal cord injury. Experimental Neurology 221: 206-216. https://doi.org/10.1016/j. expneurol.2009.10.024

LAVDAS A., PAPASTEFANAKI F., THOMAIDOU D., MATSAS R. (2011). Cell Adhesion Molecules in Gene and Cell Therapy Approaches for Nervous System Repair. Current Gene Therapy 11: 90-100. https://doi.org/10.2174/156652311794940755

LEE-LIU D., EDWARDS-FARET G., TAPIA V. S., LARRAÍN J. (2013). Spinal cord regeneration: Lessons for mammals from non-mammalian vertebrates. genesis 51: 529-544. https://doi.org/10.1002/dvg.22406

LI Q., CHENG Z., ZHOU L., DARMANIS S., NEFF N. F., OKAMOTO J., GULATI G. BENNETT M. L., SUN L. O., CLARKE L. E., MARSCHALLINGER J., YU G., QUAKE S. R., WYSS-CORAY T., BARRES B. A. (2019). Developmental Heterogeneity of Microglia and Brain Myeloid Cells Revealed by Deep Single-Cell RNA Sequencing. Neuron 101: 207-223.e10. https://doi.org/10.1016/j.neuron.2018.12.006

LI Y., HE X., KAWAGUCHI R., ZHANG Y., WANG Q., MONAVARFESHANI A., YANG Z., CHEN B., SHI Z., MENG H., ZHOU S., ZHU J., JACOBI A., SWARUP V., POPOVICH P. G., GESCHWIND D. H., HE Z. (2020). Microglia-organized scar-free spinal cord repair in neonatal mice. Nature 587: 613-618. https://doi.org/10.1038/ s41586-020-2795-6

LIU K., LU Y., LEE J. K., SAMARA R., WILLENBERG R., SEARS-KRAXBERGER I., TEDESCHI A., PARK K. K., JIN D., CAI B., XU B., CONNOLLY L., STEWARD O., ZHENG B., HE Z. (2010). PTEN deletion enhances the regenerative ability of adult corticospinal neurons. Nature Neuroscience 13: 1075-1081. https://doi. org/10.1038/nn.2603

LIU Y., WANG X., LI W., ZHANG Q., LI Y., ZHANG Z., ZHU J., CHEN B., WILLIAMS P. R., ZHANG Y., YU B., GU X., HE Z. (2017). A Sensitized IGF1 Treatment Restores Corticospinal Axon-Dependent Functions. Neuron 95: 817-833.e4. https://doi. org/10.1016/j.neuron.2017.07.037

LLORENS-BOBADILLA E., CHELL J. M., LE MERRE P., WU Y., ZAMBONI M., BERGENSTRÅHLE J., STENUDD M., SOPOVA E., LUNDEBERG J., SHUPLIAKOV O. CARLÉN M., FRISÉN J. (2020). A latent lineage potential in resident neural stem cells enables spinal cord repair. Science 370: eabb8795. https://doi.org/10.1126/ science.abb8795

LU P., KADOYA K., TUSZYNSKI M. H. (2014). Axonal growth and connectivity from neural stem cell grafts in models of spinal cord injury. Current Opinion in Neurobiology 27: 103-109. https://doi.org/10.1016/j.conb.2014.03.010

LU P., WANG Y., GRAHAM L., MCHALE K., GAO M., WU D., BROCK J., BLESCH A., ROSENZWEIG E. S., HAVTON L. A., ZHENG B., CONNER J. M., MARSALA M., TUSZYNSKI M. H. (2012). Long-Distance Growth and Connectivity of Neura Stem Cells after Severe Spinal Cord Injury. Cell 150: 1264-1273. https://doi. org/10.1016/j.cell.2012.08.020
MANSOUR A. A.F., GONÇALVES J. T., BLOYD C. W., LI H., FERNANDES S., QUANG D., JOHNSTON S., PARYLAK S. L., JIN X., GAGE F. H. (2018). An in vivo mode of functional and vascularized human brain organoids. Nature Biotechnology 36 432-441. https://doi.org/10.1038/nbt.4127

MANSOUR A. A.F., SCHAFER S. T., GAGE F. H. (2021). Cellular complexity in brain organoids: Current progress and unsolved issues. Seminars in Cell \& Developmental Biology 111: 32-39. https://doi.org/10.1016/j.semcdb.2020.05.013

MAR F. M., BONNI A., SOUSA M. M. (2014). Cell intrinsic control of axon regeneration. EMBO reports 15: 254-263. https://doi.org/10.1002/embr.201337723

MARQUES S., ZEISEL A., CODELUPPI S., VAN BRUGGEN D., MENDANHA FALCÃO A., XIAO L., LI H., HÄRING M., HOCHGERNER H., ROMANOV R. A., GYLLBORG D., MUÑOZ-MANCHADO A. B., LA MANNO G., LÖNNERBERG P., FLORIDDIA E. M., REZAYEE F., ERNFORS P., ARENAS E., HJERLING-LEFFLER J., HARKANY T., RICHARDSON W. D., LINNARSSON S., CASTELO-BRANCO G. (2016). Oligodendrocyte heterogeneity in the mouse juvenile and adult central nervous system. Science 352: 1326-1329. https://doi.org/10.1126/science.aaf6463

MATSAS R., LAVDAS A., PAPASTEFANAKI F., THOMAIDOU D. (2008). Schwann Cell Transplantation for CNS Repair. Current Medicinal Chemistry 15: 151-160. https:// doi.org/10.2174/092986708783330593

MEINHARDT A., EBERLE D., TAZAKI A., RANGA A., NIESCHE M., WILSCH-BRÄUNINGER M., STEC A., SCHACKERT G., LUTOLF M., TANAKA E. M. (2014). 3D Reconstitution of the Patterned Neural Tube from Embryonic Stem Cells. Stem Cell Reports 3: 987-999. https://doi.org/10.1016/j.stemcr.2014.09.020

MELETIS K., BARNABÉ-HEIDER F., CARLÉN M., EVERGREN E., TOMILIN N. SHUPLIAKOV O., FRISÉN J. (2008). Spinal Cord Injury Reveals Multilineage Differentiation of Ependymal Cells. PLoS Biology 6: e182. https://doi.org/10.1371/ journal.pbio.0060182

MOKALLED M. H., PATRA C., DICKSON A. L., ENDO T, STAINIER D. Y. R., POSS K D. (2016). Injury-induced ctgfa directs glial bridging and spinal cord regeneration in zebrafish. Science 354: 630-634. https://doi.org/10.1126/science.aaf2679

MUNCE S. E. P., WEBSTER F., FEHLINGS M. G., STRAUS S. E., JANG E., JAGLAL S. B. (2016). Meaning of self-management from the perspective of individuals with traumatic spinal cord injury, their caregivers, and acute care and rehabilitation managers: an opportunity for improved care delivery. BMC Neurology 16: 11 https://doi.org/10.1186/s12883-016-0534-2

O'SHEA T. M., BURDA J. E., SOFRONIEW M. V. (2017). Cell biology of spinal cord injury and repair. Journal of Clinical Investigation 127: 3259-3270. https://doi. org/10.1172/JCI90608

OGURA T., SAKAGUCHI H., MIYAMOTO S., TAKAHASHI J. (2018). Three-dimensional induction of dorsal, intermediate and ventral spinal cord tissues from human pluripotent stem cells. Development 145: dev.162214. https://doi.org/10.1242/ dev. 162214

OLMSTED Z. T., PALUH J. L. (2021). Co-development of central and peripheral neurons with trunk mesendoderm in human elongating multi-lineage organized gastruloids. Nature Communications 12: 3020. https://doi.org/10.1038/s41467-021-23294-7

OLMSTED Z. T., STIGLIANO C., BADRI A., ZHANG F., WILLIAMS A., KOFFASM. A. G., XIE Y., LINHARDT R. J., CIBELLI J., HORNER P. J., PALUH J. L. (2020). Fabrication of homotypic neural ribbons as a multiplex platform optimized for spinal cord delivery. Scientific Reports 10: 12939. https://doi.org/10.1038/s41598-020-69274-7

OTTOBONI L., VON WUNSTER B., MARTINO G. (2020). Therapeutic Plasticity of Neural Stem Cells. Frontiers in Neurology 11: 148. https://doi.org/10.3389/ fneur.2020.00148

OUDEGA M., PEREZ M. A. (2012). Corticospinal reorganization after spinal cord injury. The Journal of Physiology 590: 3647-3663. https://doi.org/10.1113/ jphysiol.2012.233189

PAPASTEFANAKI F., CHEN J., LAVDAS A. A., THOMAIDOU D., SCHACHNER M. MATSAS R. (2007). Grafts of Schwann cells engineered to express PSA-NCAM promote functional recovery after spinal cord injury. Brain 130:2159-2174. https:// doi.org/10.1093/brain/awm155

PAPASTEFANAKI F., JAKOVCEVSKI I., POULIA N., DJOGO N., SCHULZ F., MARTINOVIC T., CIRIC D., LOERS G., VOSSMEYER T., WELLER H., SCHACHNER M., MATSAS R. (2015). Intraspinal Delivery of Polyethylene Glycol-coated Gold Nanoparticles Promotes Functional Recovery After Spinal Cord Injury. Molecular Therapy 23: 993-1002. https://doi.org/10.1038/mt.2015.50

PAPASTEFANAKI F., MATSAS R. (2015). From demyelination to remyelination : The road toward therapies for spinal cord injury . Glia 63: 1101-1125. https://doi. org/10.1002/glia.22809 
PARK K. K., LIU K., HU Y., SMITH P. D., WANG C., CAI B., XU B., CONNOLLY L., KRAMVIS I., SAHIN M., HE Z. (2008). Promoting Axon Regeneration in the Adult CNS by Modulation of the PTEN/mTOR Pathway. Science 322: 963-966. https:// doi.org/10.1126/science.1161566

POPLAWSKI G. H. D., KAWAGUCHI R., VAN NIEKERK E., LU P., MEHTA N., CANETE P., LIE R., DRAGATSIS I., MEVES J. M., ZHENG B., COPPOLA G., TUSZYNSKI M. H. (2020). Injured adult neurons regress to an embryonic transcriptional growth state. Nature 581: 77-82. https://doi.org/10.1038/s41586-020-2200-5

ROSENZWEIG E. S., BROCK J. H., LU P., KUMAMARU H., SALEGIO E. A., KADOYA K., WEBER J. L., LIANG J. J., MOSEANKO R., HAWBECKER S., HUIE J. R., HAVTON L. A., NOUT-LOMAS Y. S., FERGUSON A. R., BEATTIE M. S., BRESNAHAN J. C., TUSZYNSKI M. H. (2018). Restorative effects of human neural stem cell grafts on the primate spinal cord. Nature Medicine 24: 484-490. https://doi. org/10.1038/nm.4502

SABERI H., FIROUZI M., HABIBI Z., MOSHAYEDI P., AGHAYAN H. R., ARJMAND B., HOSSEINI K., RAZAVI H. E., YEKANINEJAD M. S. (2011). Safety of intramedullary Schwann cell transplantation for postrehabilitation spinal cord injuries: 2-year follow-up of 33 cases. Journal of Neurosurgery: Spine 15: 515-525. https://doi. org/10.3171/2011.6.SPINE10917

SAHU S., SHARAN S. K. (2020). Translating Embryogenesis to Generate Organoids: Novel Approaches to Personalized Medicine. iScience 23: 101485. https://doi. org/10.1016/j.isci.2020.101485

SCHAFER D. P., LEHRMAN E. K., KAUTZMAN A. G., KOYAMA R., MARDINLY A R., YAMASAKI R., RANSOHOFF R. M., GREENBERG M. E., BARRES B. A., STEVENS B. (2012). Microglia Sculpt Postnatal Neural Circuits in an Activity and Complement-Dependent Manner. Neuron 74: 691-705. https://doi.org/10.1016/j. neuron.2012.03.026

SILVA N. A., SOUSA N., REIS R. L., SALGADO A. J. (2014). From basics to clinical: A comprehensive review on spinal cord injury. Progress in Neurobiology 114: 25-57. https://doi.org/10.1016/j.pneurobio.2013.11.002

SILVER J., SCHWAB M. E., POPOVICH P. G. (2014). Central Nervous System Regenerative Failure: Role of Oligodendrocytes, Astrocytes, and Microglia. Cold Spring Harbor Perspectives in Biology 7: a020602. https://doi.org/10.1101/cshperspect.a020602

FEHLINGS M., SINGH A., TETREAULT L., KALSI-RYAN S., NOURI A. (2014). Global prevalence and incidence of traumatic spinal cord injury. Clinical Epidemiology 6: 309-331. https://doi.org/10.2147/CLEP.S68889
SMITH E. M., BOUCHER N., MILLER W. C. (2016). Caregiving services in spinal cord injury: a systematic review of the literature. Spinal Cord 54: 562-569. https://doi. org/10.1038/sc. 2016.8

SOLDNERF., JAENISCH R. (2018). Stem Cells, Genome Editing, and the Path to Translational Medicine. Cell 175: 615-632. https://doi.org/10.1016/j.cell.2018.09.010

STERNFELD M. J., HINCKLEY C. A., MOORE N. J., PANKRATZ M. T., HILDE K L., DRISCOLL S. P., HAYASHI M., AMIN N. D., BONANOMI D., GIFFORD W. D., SHARMA K., GOULDING M., PFAFF S. L. (2017). Speed and segmentation control mechanisms characterized in rhythmically-active circuits created from spinal neurons produced from genetically-tagged embryonic stem cells. eLife 6: e21540. https://doi.org/10.7554/eLife.21540

TEDESCHI A., BRADKE F. (2017). Spatial and temporal arrangement of neuronal intrinsic and extrinsic mechanisms controlling axon regeneration. Current Opinion in Neurobiology 42: 118-127. https://doi.org/10.1016/j.conb.2016.12.005

TZOUANACOU E., WEGENER A., WYMEERSCH F. J., WILSON V., NICOLAS J.F. (2009). Redefining the Progression of Lineage Segregations during Mammalian Embryogenesis by Clonal Analysis. Developmental Cell 17: 365-376. https://doi. org/10.1016/j.devcel.2009.08.002

VISMARA I.,PAPA S., ROSSI F., FORLONI G., VEGLIANESEP. (2017). Current Options for Cell Therapy in Spinal Cord Injury. Trends in Molecular Medicine 23: 831-849. https://doi.org/10.1016/j.molmed.2017.07.005

WANG J., HE X., MENG H., LI Y., DMITRIEV P., TIAN F., PAGE J. C., LU Q. R., HE Z. (2020a). Robust Myelination of Regenerated Axons Induced by Combined Manipulations of GPR17 and Microglia. Neuron 108: 876-886.e4. https://doi. org/10.1016/j.neuron.2020.09.016

WANG Z., WANG S.N., XU T.Y., HONG C., CHENG M.H., ZHU P.X., LIN J.S., SU D.F MIAO C.Y. (2020b). Cerebral organoids transplantation improves neurological motor function in rat brain injury. CNS Neuroscience \& Therapeutics 26: 682-697. https://doi.org/10.1111/cns.13286

ZHOU, X., HE, X., REN, Y. (2014). Function of microglia and macrophages in secondary damage after spinal cord injury. Neural Regeneration Research 9: 1787-1795. https://doi.org/10.4103/1673-5374.143423

ZUKOR K. A., KENT D. T., ODELBERG S. J. (2011). Meningeal cells and glia establish a permissive environment for axon regeneration after spinal cord injury in newts. Neural Development 6: 1. https://doi.org/10.1186/1749-8104-6-1 